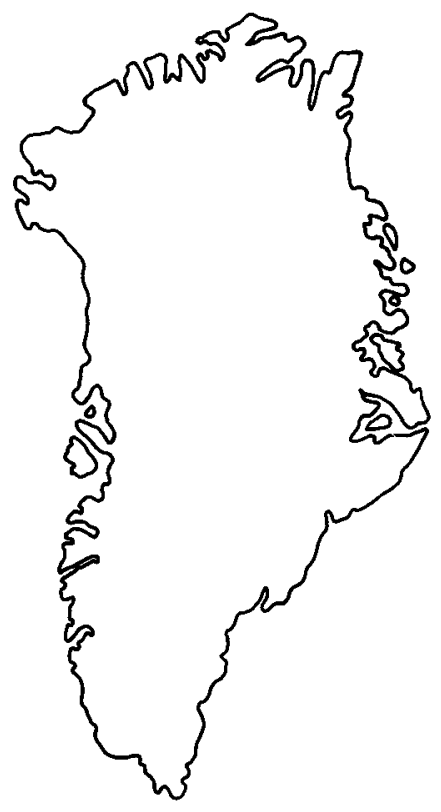

\title{
Sm-Nd isotope age data from the Archaean Skjoldungen area, South-East Greenland
}

\author{
Feiko Kalsbeek and Paul N. Taylor
}

\begin{abstract}
Sm-Nd model ages for ten basement gneisses and intrusive rocks from the Skjoldungen area in South-East Greenland range from 2.73 to $2.91 \mathrm{Ga}$. Two rocks yielded older ages: a high-grade metasedimentary rock $(2.96 \mathrm{Ga})$ and a pegmatite $(3.13 \mathrm{Ga})$. $\mathrm{Sm}-\mathrm{Nd}$ data are now available for a more than $700 \mathrm{~km}$ long stretch of the south-east coast of Greenland between $63^{\circ}$ and $68^{\circ} \mathrm{N}$. No evidence has been found for the presence of early Archaean ( $>3.5 \mathrm{Ga}$ ) rocks, and early Proterozoic gneisses have only been found in the Ammassalik area $\left(65^{\circ} 30^{\prime} \mathrm{N}\right)$.
\end{abstract}

F. K., Geological Survey of Greenland, Øster Voldgade 10, DK-1350 Copenhagen K, Denmark.

P. N. T., Department of Earth Sciences, University of Oxford, Oxford OXI 3PR, United Kingdom (Present address: Woodstock School, Mussoorie, U.P. 248179, India).

Field work in preparation for GGU's 1:500 000 map sheet 14, 'Skjoldungen' (Escher, 1990) was carried out in the summer of 1987 (Nielsen \& Escher, 1988). Most of the area consists of various kinds of high-grade (amphibolite to granulite facies) orthogneisses (Fig. 1). In the area centred about the island Skjoldungen a number of intrusions, up to more than $10 \mathrm{~km}$ in diameter, were distinguished, ranging in composition from gabbro and hornblende diorite to (nepheline-) syenite (Nielsen \& Rosing, 1990; Rosing et al., 1992; Blichert-Toft et al., 1992, 1993). This suite has been termed the 'Skjoldungen alkaline province' by Nielsen \& Rosing (1990). Many of the intrusions were emplaced at a late stage in the evolution of the area - they are undeformed and display well-preserved igneous structures. Others are strongly deformed and migmatised (Nielsen \& Rosing, 1990). In the same general area high-grade metasedimentary rocks (garnet-sillimanite paragneisses) are fairly common.

The region has been divided into three sub-areas: (1) an area dominated by agmatitic orthogneisses in the south-west; (2) the central area characterised by late intrusions and common occurrences of metasediments; and (3) the area to the north-east, dominated by nonagmatitic gneisses (Fig. 1). It has been suggested that the geological variation from south-west to north-east may represent a major discontinuity, the central subarea with its occurrences of metasediments and late intrusions representing a suture zone between two distinct Archaean terrains to the north-east and south-west
(M. T. Rosing, personal communication, 1989). In this paper we present $\mathrm{Sm}-\mathrm{Nd}$ model age data on samples from basement gneisses, from several late intrusions and from a metasediment.

\section{Field setting of analysed rocks and Sm-Nd model ages}

Samples were collected at a number of localities scattered throughout the area (Fig. 2) and Sm-Nd analyses carried out on one or a few samples from each locality at the Age and Isotope Laboratory at Oxford University. Analytical data (Table 1) were calculated into model ages, $T_{D M}$, according to the depleted mantle model of DePaolo (1981). These model ages can be regarded as an estimate of the time elapsed since the $\mathrm{Nd}$ in the rocks was incorporated into the crust. In rocks with a complex origin the model ages may not have a direct chronological meaning: the Nd in such rocks may be a mixture of $\mathrm{Nd}$ components extracted from the mantle at different times. For metasediments $\mathrm{Sm}-\mathrm{Nd}$ model ages give an estimate of the age of the source region of the original sediment.

Analytical errors in the $\mathrm{Sm}-\mathrm{Nd}$ data give rise to an uncertainty of about $0.02-0.04 \mathrm{Ga}$ in $\mathrm{T}_{\mathrm{DM}}$ values $(0.07$ Ga for GGU 311877), dependent on the ${ }^{147} \mathrm{Sm} /{ }^{144} \mathrm{Nd}$ ratios of the samples. Interpretation of $T_{D M}$ values in terms of rock ages is complicated by (1) the possibility of mixing of $\mathrm{Nd}$ from various sources in the analysed rock and (2) by the uncertainty in how far the mantle 


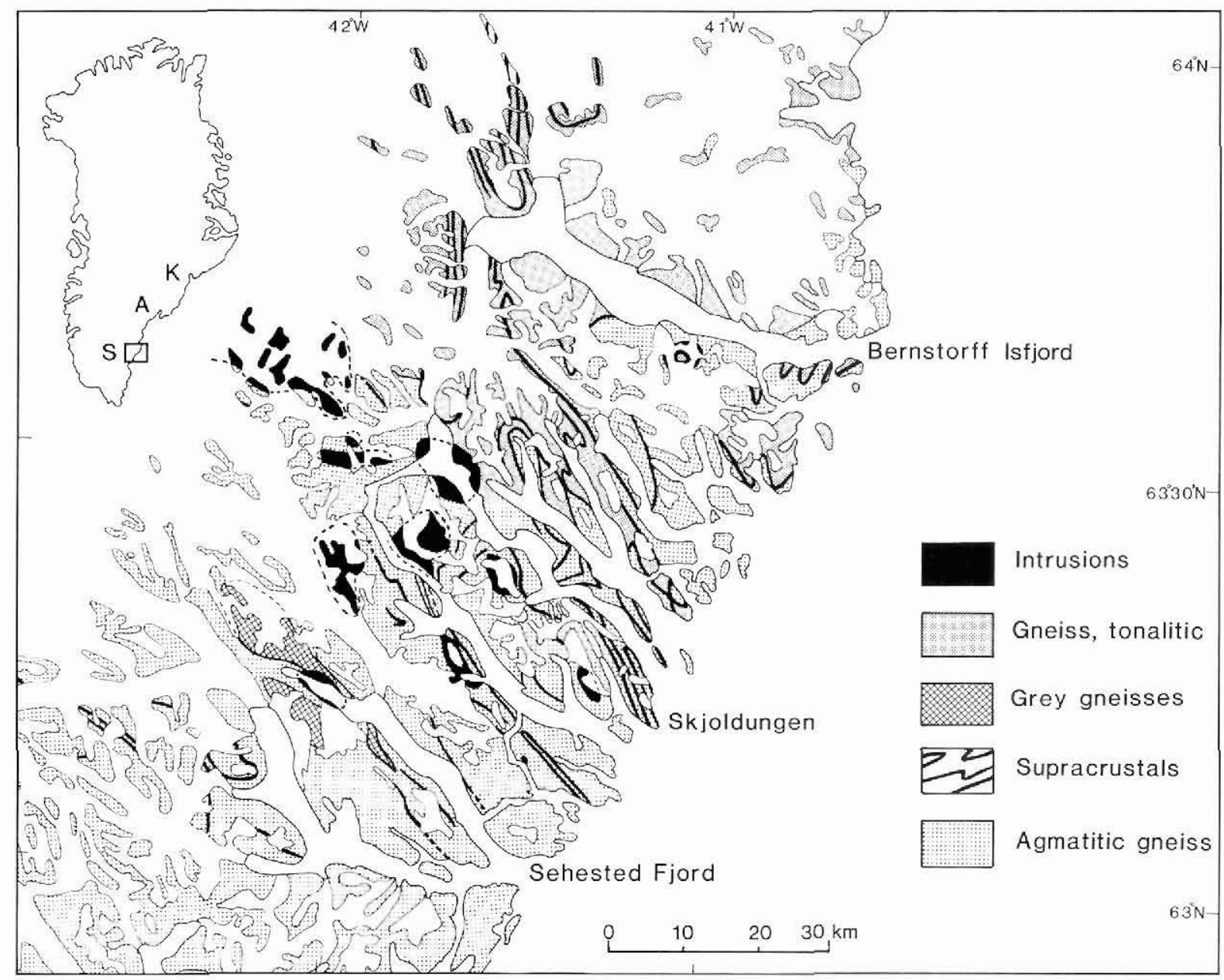

Fig. 1. Geological sketch map of the Skjoldungen area, after Nielsen \& Escher (1988). The inset shows the location of the Skjoldungen area in South-East Greenland (S), Ammassalik (A) and Kangerdlugssuaq (K).

model used to predict the initial Nd-isotopic composition is appropriate. Sm-Nd model ages are therefore of a reconnaissance nature only.

Two samples (311871 and -877) are from a sequence of supracrustal rocks at $63^{\circ} 12.5^{\prime} \mathrm{N} ; 41^{\circ} 08^{\prime} \mathrm{W}$ (1 in Fig. 2). The sequence is dominated by ultramafic and mafic rocks. interpreted as metavolcanics, and contains minor proportions of metasedimentary rocks, such as garnetsillimanite paragneiss. Sample 311871 is a paragneiss and yielded a $\mathrm{T}_{\mathrm{DM}}$ value of $2.96 \mathrm{Ga}$. Sample 311877 is an amphibolitic metavolcanic rock with $\mathrm{T}_{\mathrm{DM}} 2.82 \mathrm{Ga}$.

Assuming that the model age of the amphibolite refers to the time of formation of its volcanic precursor, deposition of the supracrustal sequence would have taken place about $2.82 \mathrm{Ga}$ ago. The $2.96 \mathrm{Ga}$ model age for the paragneiss sample suggests that the source area of the sedimentary parent of the paragneiss consisted of rocks only 100-200 Ma older than deposition of the supracrustal rocks.

Three samples (311909, -927 and -934) were collected from the regional gneisses: 311909 from the south-western part of the area $\left(62^{\circ} 49.5^{\prime} \mathrm{N} ; 42^{\circ} 37.5^{\prime} \mathrm{W}, 2\right.$ in Fig. 2), and 311927 and -934 from the north-east $\left(63^{\circ} 20.5^{\prime} \mathrm{N} ; 41^{\circ} 07^{\prime} \mathrm{W}\right.$ and $63^{\circ} 21^{\prime} \mathrm{N} ; 41^{\circ} 07^{\prime} \mathrm{W}, 3$ in Fig. 2). Sample 311909 is a homogeneous pegmatite sheet within agmatitic gneisses. It yielded the oldest $\mathrm{T}_{\mathrm{DM}}$ date in this survey $(3.13 \mathrm{Ga})$. We do not know to what extent this date is representative for the gneisses in this part of the area. The localities studied consist of very inhomogeneous gneisses with abundant half-digested inclusions, and it was not possible to collect sufficiently large samples consisting of a single homogeneous lithology.

Samples 311927 and -934 from the north-eastern part of the area represent, respectively, a fairly homogen- 
eous, grey, banded, tonalitic gneiss, and the leucosome component in an agmatitic gneiss. They yielded $\mathrm{T}_{\mathrm{DM}}$ values of 2.88 and $2.84 \mathrm{Ga}$, respectively.

Three samples analysed (311811, 348051 and 348056) are from undeformed intrusive rocks: 311811 is a nephclinitic rock from the Singertât intrusion $\left(63^{\circ} 14^{\prime} \mathrm{N}\right.$; $42^{\circ} 02^{\prime} \mathrm{W} . \mathrm{S}$ in Fig. 2; see Nielsen \& Rosing, 1990); 348051 and -056 are a syenite and a leucogabbro, respectively, from an alkaline intrusive complex at Sfinksen on Skjoldungen (63 $23.4^{\prime} \mathrm{N} ; 41^{\circ} 45.5^{\prime} \mathrm{W}$. Sf in Fig. 2). Sm-Nd model ages $\left(T_{D M}\right)$ for these rocks are, respectively, 2.78, 2.81 and $2.82 \mathrm{Ga}$. This is about $0.1 \mathrm{Ga}$ older than zircon U-Pb dates obtained for these rocks: $2.67 \mathrm{Ga}$ for zircon from the Singertât nepheline-syenite complex (B. T. Hansen, personal communication, 1989 ) and 2.70 Ga for a syenite from the Ruinnæsset intrusive complex ( $\mathrm{R}$ in Fig. 2; A. P. Nutman and M. T. Rosing, personal communication, 1993). There is evidence that a depleted mantle model may not be appropriate for a reliable estimate of the time of formation of these rocks (Blichert-Toft et al., 1993). In fact, model ages calculated with respect to a non-depleted mantle, $\mathrm{T}_{\text {Cuur }}$ (DePaolo \& Wasserburg, 1976; Table 1), are in better agreement with the zircon dates (2.61 Ga for the Singertât sample and $2.67 \mathrm{Ga}$ for samples from the Sfinksen complex). Alternatively, the discrepancy between $T_{D M}$ values and zircon dates may result from a small component of slightly older continental crustal material in these rocks.

Sample 311834 was collected at $63^{\circ} 09^{\prime} \mathrm{N}$ : $41^{\circ} 58^{\prime} \mathrm{W}$ (4 in Fig. 2) from a syenitic gneiss, perhaps related to the alkaline igneous activity in the region. This rock is strongly deformed and therefore probably older than

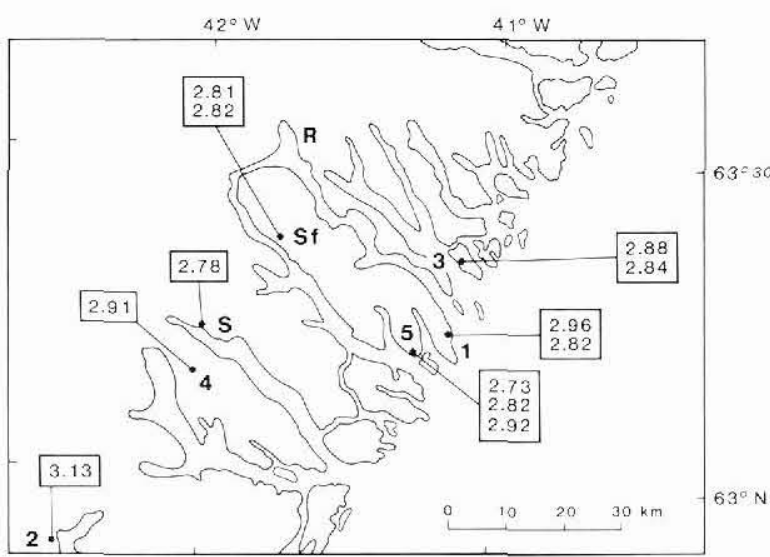

Fig. 2. Location of the analysed samples and the resulting model ages $\left(\mathrm{T}_{\mathrm{DM}}\right)$ in Ga. The localities are numbered for reference in the text. S: Singertât: Sf: Sfinksen; R: Ruinnæsset.
Table 1. Sm-Nd isotope data and model ages for Archaean rocks from the Skjoldungen area, South-East Greenland

\begin{tabular}{|c|c|c|c|c|c|c|}
\hline $\begin{array}{c}\text { Sample } \\
\text { no }\end{array}$ & $\underset{(\mathrm{ppm})}{\mathrm{Sm}}$ & $\begin{array}{c}\mathrm{Nd} \\
(\mathrm{ppm})\end{array}$ & ${ }^{14} \mathrm{Sm} / l^{1+4} \mathrm{Nd}$ & ${ }^{143} \mathrm{Nd} /{ }^{1+4} \mathrm{Nd}$ & $\begin{array}{l}\mathrm{T}_{\mathrm{DM}} \\
\text { (Ga) }\end{array}$ & $\begin{array}{l}\mathrm{T}_{\text {CHLR }} \\
\text { (Ga) }\end{array}$ \\
\hline $311811 *$ & 2.099 & 12.167 & 0.1043 & 0.511050 & 2.78 & 2.61 \\
\hline 311834 & 15.618 & 114.640 & 0.0824 & 0.510541 & 2.91 & 2.78 \\
\hline 311860 & 8.946 & 48.739 & 0.1110 & 0.511203 & 2.73 & 2.54 \\
\hline 311863 & 0.623 & 6.592 & 0.0571 & 0.510142 & 2.82 & 2.71 \\
\hline 311868 & 0.576 & 6.107 & 0.0570 & 0.510045 & 2.92 & 2.81 \\
\hline 311871 & 3.328 & 15.550 & 0.1294 & 0.511414 & 2.96 & 2.76 \\
\hline 311877 & 2.244 & 8.218 & 0.1651 & 0.512153 & 2.82 & 2.33 \\
\hline 311909 & 0.984 & 6.197 & 0.0960 & 0.510635 & 3.13 & 3.01 \\
\hline 311927 & 5.153 & 33.212 & 0.0938 & 0.510779 & 2.88 & 2.74 \\
\hline 311934 & 4.235 & 27.729 & 0.0923 & 0.510785 & 2.84 & 2.69 \\
\hline $348051^{*}$ & 6.669 & 46.086 & 0.0875 & 0.510716 & 2.81 & 2.67 \\
\hline $348056^{\circ}$ & 12.473 & 80.944 & 0.0931 & 0.510816 & 2.82 & 2.67 \\
\hline
\end{tabular}

Isotope data determined at the Age and Isotope Laboratory, Department of Earth Sciences, University of Oxford. Analytical uncertainties are estimated as c. $0.1 \%$ for $\mathrm{Sm}$ and $\mathrm{Nd}$ concentrations, $0.2 \%$ for ${ }^{147} \mathrm{Sm} /{ }^{14} \mathrm{Nd}$, and 0.00001 for ${ }^{1+3} \mathrm{Nd} /{ }^{14+} \mathrm{Nd}$ ( 1 sigma values). $T_{D M}$ and $T_{C H t R}$ values are model ages calculated according to the depleted mantle model of DePaolo (1981) and relative to undepleted mantle (DePaolo \& Wasserburg, 1976), respectively. Samples marked with an asterisk are from late Archaean alkaline igneous complexes.

the non-deformed igneous rocks. It yielded a $\mathrm{T}_{\mathrm{Dm}}$ value of $2.91 \mathrm{Ga}$.

Three samples $(311860,-363$ and -868$)$ were taken from a gabbro/diorite complex and its country rock at $63^{\circ} 12^{\prime} \mathrm{N} ; 41^{\circ} 15^{\prime} \mathrm{W}$ (5 in Fig. 2). Gabbroic and dioritic rocks are here locally well preserved and may snow igneous layering, but at other places they are strongly deformed. The complex is cut by granite sheets and surrounded by agmatitic gneisses with inclusions, which could not be distinguished in the field from deformed dioritic rocks within the complex. Sample no 311860 is a well preserved gabbro and yielded a $\mathrm{T}_{1 \mathrm{pM}}$ date of 2.73 $\mathrm{Ga}, 311863$ is a granite sheet in gabbro with $\mathrm{T}_{\mathrm{DM}} 2.82$ $\mathrm{Ga}$, and 311868 represents the leucosome of agmatitic rocks surrounding the gabbro/diorite complex and gave a $T_{D M}$ value of $2.92 \mathrm{Ga}$. Taken at face value, the range of $T_{D M}$ values would appear to be in conflict with the ficld observations. The granite sheet $(2.82 \mathrm{Ga})$ is certainly younger than the gabbro $(2.73 \mathrm{Ga})$ and this may also be the case for the surrounding agmatitic gneiss $(2.92 \mathrm{Ga})$. However, other gabbroic intrusions in the area were evidently emplaced into gneissic basement. It is possible that the investigated gabbro was also intruded into older gneisses, which caused anatexis, with 


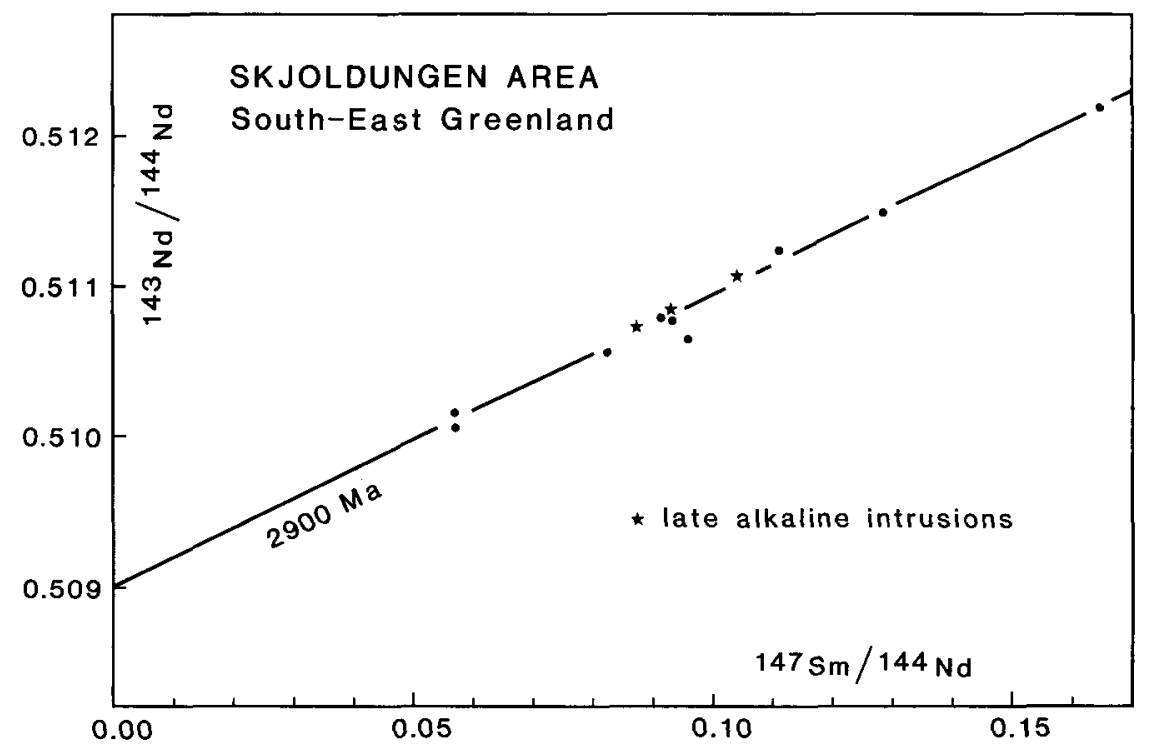

Fig. 3. Sm-Nd isochron diagram for samples from the Skjoldungen area, South-East Greenland. The $2900 \mathrm{Ma}$ isochron with $\mathrm{Nd}_{\mathrm{i}} 0.5090$ is shown for reference only. the result that older basement material could intrude into younger gabbro.

With the exception of pegmatitic rock 311909 , all samples plot close to a reference isochron with an initial ${ }^{143} \mathrm{Nd} /{ }^{144} \mathrm{Nd}$ ratio $\left(\mathrm{Nd}_{\mathrm{i}}\right)$ of 0.5090 and a slope corresponding to an age of $2.9 \mathrm{Ga}$ (Fig. 3). Apparently all the rocks formed within a restricted period of time during the late Archaean from a source with a restricted range of $\mathrm{Nd}$ isotopic compositions. The $\mathrm{Nd}_{\mathrm{i}}$ value of 0.5090 at $2.9 \mathrm{Ga}$ corresponds to an $\varepsilon_{\mathrm{CHUR}}$ value of +2.5 , not significantly different from the expected value of +1.9 calculated for the depleted mantle model of DePaolo (1981).

\section{Discussion}

Sm-Nd data are now available for about 40 samples scattered along a more than $700 \mathrm{~km}$ long stretch of the coast of South-East Greenland between Skjoldungen $\left(63^{\circ} \mathrm{N}\right)$ and Kangerdlugssuaq $\left(68^{\circ} \mathrm{N}\right.$, Fig. 1, inset) (this paper; Taylor et al., 1992; Kalsbeek et al., in press). With few exceptions, model ages $\left(T_{D M}\right)$ fall in the range of 2750 to $3000 \mathrm{Ma}$. In the Ammassalik area (c. $\left.65^{\circ} 30^{\prime} \mathrm{N}\right)$ rocks with younger $\mathrm{T}_{\mathrm{DM}}$ values $(2.1-2.2 \mathrm{Ga}$ ) are also present. These were formed during formation of the early Proterozoic 'Ammassalik Mobile Belt' (Kalsbeek, 1989; Kalsbeek et al., in press). Nowhere in this region has evidence been found for the presence of early Archaean rocks comparable in age with the 3.6-3.9 Ga Amîtsoq gneisses in the Godthåbsfjord area of West Greenland (McGregor, 1973).

The Archaean age of the well-preserved alkaline intrusions in the Skjoldungen area, now confirmed by zircon U-Pb dating, was a surprise; Archaean alkaline rocks are rare but not unknown (see Nielsen \& Rosing, 1990).

Acknowledgements. Analyses were carried out at the Age and Isotope Laboratory, Department of Earth Sciences, University of Oxford. We thank Professor S. Moorbath for his permission to use these facilities, and we gratefully acknowledge his continued support of our work. Figures were prepared by Grethe Fuglsang Hansen.

\section{References}

Blichert-Toft, J., Rosing, M. T. \& Lesher, C. E. 1992: Field relations and geochemistry of the Ruinnæsset intrusion and related magmatic rocks of the Archaean Skjoldungen province, East Greenland. Eos 73, suppl. (1992 spring meeting), 331-332.

Blichert-Toft, J., Rosing, M. T., Lescher, C. E. \& Chauvel, C. in press: Trace element and $\mathrm{Sr}$ and $\mathrm{Nd}$ isotope geochemistry of the late Archaean alkaline Ruinnæsset intrusion of the Skjoldungen province, SE Greenland. Terra abstracts.

DePaolo, D. J. 1981: Neodymium isotopes in the Colorado Front Range and crust-mantle evolution in the Proterozoic. Nature, Lond. 291, 193-196.

DePaolo, D. J. \& Wasserburg, G. J. 1976: Nd isotopic variations and petrogenetic models. Geophys. Res. Lett. 3, 249 252.

Escher, J. C. (compiler) 1990: Geological map of Greenland 1:500 000, sheet 14, Skjoldungen. Copenhagen: Geol. Surv. Greenland.

Kalsbeek, F. (ed.) 1989: Geology of the Ammassalik region, South-East Greenland. Rapp. Grønlands geol. Unders. 146, 106 pp.

Kalsbeek, F., Austrheim, H., Bridgwater, D., Hansen, B. T., Pedersen, S. \& Taylor, P. N. in press: Geochronology of Archaean and Proterozoic events in the Ammassalik area, 
South-East Greenland, and comparisons with the Lewisian of Scotland and the Nagssugtoqidian of West Greenland. Precambrian Res.

McGregor, V. R. 1973: The early Precambrian gneisses of the Godthåb district, West Greenland. Phil. Trans. R. Soc. Lond. A 273, 343-358.

Nielsen, T. F. D. \& Escher, J. C. 1988: Reconnaissance investigations in the Skjoldungen region, South-East Greenland. Rapp. Gronlands geol. Unders. 140, 72-76.

Nielsen, T. F. D. \& Rosing, M. T. 1990: The Archaean Skjoldungen alkaline province, South-East Greenland. Rapp. Grønlands geol. Unders. 148, 93-100.
Rosing, M. T., Lescher, C. E., Thomsen, H. S. \& BlichertToft, J. 1992: Alkaline magmatism in the Archaean Skjoldungen province, East Greenland. Eos 73, suppl. (1992 spring meeting), 331 only.

Taylor, P. N., Kalsbeek, F. \& Bridgwater, D. 1992: Discrepancies between neodymium, lead and strontium model ages from the Precambrian of southern East Greenland: Evidence for a Proterozoic granulite-facies event affecting Archaean gneisses. Chem. Geol. (Isot. Geosci. Sect.) 94, 281291. 